\title{
The Effect of Poisonous Range Plants on Abortions in Livestock
}

\author{
By Kevin D. Welch, T. Zane Davis, Kip E. Panter, \\ James A. Pfister, and Benedict T. Green
}

$\mathrm{N}$ atural toxins from plants and fungi, in addition to manmade toxicants, have been implicated in abortion, embryonic death, and neonatal loss in livestock. ${ }^{1}$ Plants causing reproductive problems for livestock can be found on most, if not all, rangelands worldwide, thus exposing livestock at various times and circumstances. The impacts of toxins from poisonous range plants on the embryo, fetus, and neonate are sometimes dramatic, and the consequences are economically important to the livestock industry. ${ }^{2}$

Historically, reproductive problems due to toxic plants often went undiagnosed and/or unreported because of fears about underlying genetic defects or the related negative impacts on the sale of breeding stock, or because the death of offspring was not associated with any visible malformation, such as cleft palate or heart anomalies. However, as more information has been developed about plants affecting reproduction, such fears have largely subsided, and producers are more open to understanding the root causes of the problems. Grazing management strategies using results of research and application of some basic concepts of toxicology have reduced losses to livestock producers. In this review several plants known to cause abortions in livestock will be discussed, with an emphasis on pine-needle-induced abortions.

\section{Pine-Needle-Induced Abortions}

Since the early 1900s livestock producers have had documented problems with pine-needle-induced abortions. Cattle often eat pine needles, and pregnant cattle that are allowed to eat pine needles can abort, resulting in dead or premature calves, retained placentas, and uterine infections. The problem is found throughout the western United States and Canada. The annual economic losses resulting from pine-needle-induced abortion have been estimated at \$6-20 million. ${ }^{3}$ Indirect losses such as increased management costs, supplemental feeding, lost forage, veterinary care, increased postpartum interval, and lighter weaning weights should also be considered.

Many pine-needle-induced abortions are caused by ponderosa pine, but other trees including lodgepole pine and common juniper also cause abortions (Table 1). Analysis of other Pinus species for isocupressic acid (ICA), the toxic compound, continues. Research has identified the toxin, the probable mechanism of abortion, and the most susceptible time periods of gestation for abortions to occur. Additionally, research has provided some guidelines on how to avoid or reduce the risk of pine-needle-induced abortion.

\section{Description of the Plant}

Ponderosa pine (Pinus ponderosa) is an abundant, extremely hardy, and drought-resistant tree. It is a large coniferous tree recognized by its yellowish-green needles (6-12 inches [18-28 cm] long) in bundles of three and its yellow and black bark (some common names include yellow pine and black jack pine). Ponderosa pine can be found throughout the western United States, southern British Columbia, and northern Mexico growing at elevations of 7,000-9,000 feet $(2,000-3,000 \mathrm{~m})$. Many of the rangelands in eastern Oregon, central and eastern Montana, northeast Wyoming, parts of Arizona and New Mexico, the Black Hills of South Dakota, and southern British Columbia have dense ponderosa pine forests where cattle have access to the trees.

Lodgepole pine (Pinus contorta) is also common in the western United States; it grows well at high elevations, and its tall, slender growth makes it excellent for commercial uses, such as poles, fences, and log buildings. Common juniper (Juniperus communis) is a low understory shrub found in forest and shrubland plant communities. Other species, listed in Table 1, grow in similar habitats.

\section{Toxin and Mechanism of Action}

The pine needle toxins that cause the abortion have been identified as labdane resin acids, including ICA and related compounds. ${ }^{4}$ Research at the Poisonous Plant Research Laboratory focused on developing the cattle assay because no suitable small animal assay appeared to provide acceptable results. The abortifacient (abortion-causing) effects of ponderosa pine needles could be consistently demonstrated in cattle by pumping into their stomachs about 6 pounds $(\sim 2-3 \mathrm{~kg})$ of freshly ground pine needles daily, starting on day 250 of gestation and continuing for 10 days or until 


\section{Table 1. Concentration of isocupressic acid (ICA) or other related metabolic compounds from selected}

species and locations

\begin{tabular}{|c|c|c|c|}
\hline Species & Common name & Location & ICA conc. (\%DW) \\
\hline \multirow[t]{4}{*}{ Abies concolor } & \multirow[t]{4}{*}{ White fir } & Arizona & n.d. \\
\hline & & California & n.d. \\
\hline & & Colorado & 0.04 \\
\hline & & Utah & n.d. \\
\hline \multirow[t]{4}{*}{ Abies lasiocarpa } & \multirow[t]{4}{*}{ Subalpine fir } & Oregon & n.d. \\
\hline & & Colorado & n.d. \\
\hline & & Idaho & 0.04 \\
\hline & & Utah & n.d. \\
\hline Abies magnifica & Red fir & California & 0.05 \\
\hline \multirow[t]{2}{*}{ Cupressus macrocarpa } & \multirow[t]{2}{*}{ Monterey cypress } & California & n.d. -0.06 \\
\hline & & New Zealand & $0.89-1.24$ \\
\hline Cupressus $X$ ovensii & & New Zealand & 0.81 \\
\hline \multirow[t]{2}{*}{ Juniperus californica } & \multirow[t]{2}{*}{ California juniper } & \multirow[t]{2}{*}{ California } & 0.93 needles \\
\hline & & & 0.05 bark \\
\hline \multirow[t]{2}{*}{ Juniperus communis } & \multirow[t]{2}{*}{ Mountain common juniper } & Colorado & $2.05-2.88$ \\
\hline & & Utah & $1.50-5.0$ \\
\hline \multirow[t]{2}{*}{ Juniperus monosperma } & \multirow[t]{2}{*}{ One seed juniper } & Arizona & 0.14 \\
\hline & & New Mexico & n.d. \\
\hline \multirow[t]{2}{*}{ Juniperus occidentalis } & \multirow[t]{2}{*}{ Western juniper } & \multirow[t]{2}{*}{ Oregon } & 0.10 \\
\hline & & & $\begin{array}{l}\text { Imbricatoloic } \\
\text { acid }=1.0\end{array}$ \\
\hline \multirow[t]{5}{*}{ Juniperus osteosperma } & \multirow[t]{5}{*}{ Utah juniper } & Utah & n.d. \\
\hline & & Nevada & 0.07 \\
\hline & & Arizona & n.d. \\
\hline & & Colorado & n.d. \\
\hline & & Utah & Agathic acid $=1.50$ \\
\hline \multirow[t]{3}{*}{ Juniperus scopulorum } & \multirow[t]{3}{*}{ Rocky mountain juniper } & Utah & 0.84 \\
\hline & & New Mexico & 0.33 \\
\hline & & Arizona & 0.42 \\
\hline Juniperus virginiana & Eastern red cedar & Nebraska & $\begin{array}{l}\text { Needles, low } \\
\text { bark, }<0.10 \text {-high }\end{array}$ \\
\hline Libocedrus decurrens & Incense cedar & Oregon & 0.07 \\
\hline \multirow[t]{4}{*}{ Picea enge/mannii } & \multirow[t]{4}{*}{ Engelmann spruce } & California & 0.27 \\
\hline & & Colorado & n.d \\
\hline & & Idaho & 0.04 \\
\hline & & Montana & 0.31 \\
\hline
\end{tabular}




\section{Table 1. Continued}

\begin{tabular}{|c|c|c|c|}
\hline Species & Common name & Location & ICA conc. (\%DW) \\
\hline & & Oregon & n.d. \\
\hline & & Utah & n.d. \\
\hline \multirow[t]{2}{*}{ Picea pungens } & \multirow[t]{2}{*}{ Colorado blue spruce } & Utah & 0.17 \\
\hline & & Colorado & n.d. \\
\hline Pinus aristata & Bristle cone pine & Colorado & $0.01-0.05$ \\
\hline \multirow[t]{5}{*}{ Pinus contorta } & \multirow[t]{5}{*}{ Lodgepole pine } & Oregon & 0.28 \\
\hline & & Idaho & 0.11 \\
\hline & & Colorado & $0.29-0.47$ \\
\hline & & Utah & 0.66 \\
\hline & & Canada (BC) & 0.45 \\
\hline \multirow[t]{4}{*}{ Pinus edulis } & \multirow[t]{4}{*}{ Pinyon pine } & Arizona & n.d. \\
\hline & & Colorado & 0.12 \\
\hline & & New Mexico & 0.10 \\
\hline & & Utah & 0.45 \\
\hline \multirow[t]{2}{*}{ Pinus flexilis } & \multirow[t]{2}{*}{ Limber pine } & Colorado & n.d. -0.06 \\
\hline & & Utah & n.d. \\
\hline Pinus jeffreyi & Jeffrey pine & California & $0.04-0.54$ \\
\hline \multirow[t]{2}{*}{ Pinus koraiensis } & \multirow[t]{2}{*}{ Korean pine } & Utah & Positive \\
\hline & & Korea & 0.02 \\
\hline Pinus monophylla & Single-leaf pinyon & Nevada & 0.32 \\
\hline Pinus patula & Patula pine & South Africa & $<0.10$ \\
\hline \multirow[t]{8}{*}{ Pinus ponderosa } & \multirow[t]{8}{*}{ Ponderosa pine } & Oregon & $0.74-1.30$ \\
\hline & & Arizona & 0.49 \\
\hline & & California & $0.08-1.35$ \\
\hline & & Utah & 0.51 \\
\hline & & Colorado & $0.49-0.58$ \\
\hline & & South Dakota & $0.10-1.30$ \\
\hline & & Wyoming & $0.58-1.11$ \\
\hline & & Germany & 0.62 \\
\hline Pinus radiata & Radiata pine & New Zealand & n.d. -0.26 \\
\hline \multirow[t]{6}{*}{ Pseudotsuga menziesii } & \multirow[t]{6}{*}{ Douglas fir } & Utah & 0.04 \\
\hline & & Colorado & 0.05 \\
\hline & & California & n.d. \\
\hline & & Idaho & n.d. \\
\hline & & Arizona & n.d. \\
\hline & & Oregon & n.d \\
\hline
\end{tabular}




\section{Table 1. Continued}

\begin{tabular}{|l|l|l|c|}
\hline \multicolumn{1}{|c|}{ Species } & Common name & Location & ICA conc. (\%DW) \\
\hline Thuja plicata & Western red cedar & Arizona & 0.42 \\
& & New Mexico & 0.33 \\
\hline & & Utah & 0.84 \\
\hline & & Germany & n.d. \\
\hline
\end{tabular}

Note: Values are for measured concentrations (dry weight [DW]) of ICA or, where otherwise noted, may include the measurement of similar, related diterpenes in samples where the indicated compound was identified and was also the major labdane acid present in the sample. n.d.=not detected $(<0.01 \%)$. Plant species highlighted in bold have been proven experimentally to induce abortions.

initiation of the abortion. Abortions occurred on average 6-8 days after the start of treatment. Chemical examination of biologically active fractions of pine needles (those that caused abortions) led chemists in their discovery of the toxin. ICA is one of several diterpene acids that occur in ponderosa pine. The abortifacient activity of ICA was verified by feeding trials as well as by intravenous injection of the pure compound. Interestingly ICA was originally identified in Monterey cypress (Cupressus macrocarpa), a tree commonly used in New Zealand as a windbreak and that has also been shown to cause abortion in cattle in that country. In theory any plant that contains enough ICA, including lodgepole pine and common juniper, could cause abortions (Table 1).

Current studies suggest pine needles induce parturition by decreasing placental blood flow resulting in lack of oxygen to the fetal calf. Ponderosa pine needles also contain several other compounds, which do not cause abortion but are toxic; these compounds appear to kill the rumen microflora. These other toxins may contribute to both the maternal and fetal toxicity seen in naturally occurring pine-needle-induced abortions. However, in the case of ponderosa pine, very few poisonous effects other than the induced abortions have been reported in field cases. Only in controlled experiments where very high levels of pine needles had been pumped into cows, or when feeding new growth pine branch tips, were some toxic effects reported.

\section{Consumption and Susceptibility}

Cattle graze few ponderosa pine needles except during the winter. ${ }^{5}$ However, once cattle begin eating pine needles, they learn to like needles and will sometimes consume large amounts. The amount eaten varies with weather events, nutrient status, and snow depth or the availability of other forages. ${ }^{6}$ Cattle will eat green or wilted needles directly from low branches, felled trees, or slash piles. They will also eat dried needles from the forest bed (Fig. 1). In pen studies cattle fed hay and pine needles free choice selected up to $20 \%$ of their diet as pine needles. Field grazing studies found that cattle will eat up to $40 \%$ of their diet as pine needles. ${ }^{7}$ Pine needle consumption and grazing times were

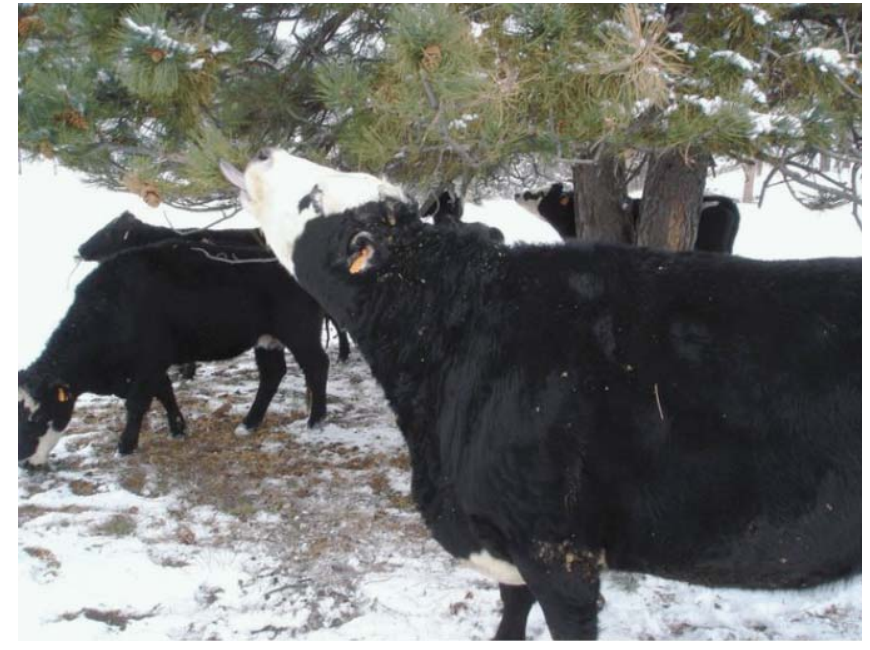

Figure 1. Cattle often eat pine needles, particularly when other forage is less available or during winter weather events.

related to ambient temperature, snow depth, and wind speed. Consumption of pine needles increased as snow depth increased and temperature decreased. Thus, the risk of pine needle consumption and possible poisonings appears to be greater during severe winters and during cold and snowy fall or spring storms. Although not determined experimentally, it is likely that there is an interaction between snow depth and reduced forage availability to cattle, often leading to their increased pine needle consumption. Nevertheless, hunger is probably not the major factor in pine needle consumption. Cattle will often leave the feed grounds, move into pine-tree-sheltered areas, and begin to consume the needles (J. A. Pfister, personal observation).

Recent research has shown that cattle in thin body condition will eat more needles than do fat cows. ${ }^{6}$ In addition, the protein content of the diet appears to influence pine needle consumption, because cattle on low-protein diets eat fewer needles than cattle on high-protein diets. Further work on interactions between cattle nutrition and needle consumption is ongoing.

Pine needle abortion has been reported to occur in cattle and buffalo (Bison bison), but not deer, elk, sheep, or goats. 
Cattle in the third trimester of pregnancy are more likely to abort or deliver premature calves when they ingest pine needles. ${ }^{8}$ Pine-needle-induced abortions can have varying morbidity, affecting up to $100 \%$ of exposed animals. Common scenarios of poisoning include situations when cattle in late gestation are forced into stands of ponderosa pine trees by winter storms or when cattle are exposed to easily accessible pine needles by logging operations or blowdowns. Abortions will occur if sufficient amounts of needles, duff, new growth, or bark are consumed.

\section{Abortion and Disease}

Response to pine needle ingestion is variable and largely dependent on gestational age, amount of needles consumed, and the concentration of ICA in the needles. ${ }^{9}$ Current research suggests that an ICA content of $0.5 \%$ in the needles, or greater, is necessary for an abortion to occur, with most abortions occurring when the ICA content of the needles is greater than $1.0 \%$. Most animals will abort within the first several days of ingesting pine needles, but some may not abort until 14-16 days later. The dose required varies; some cattle abort after a single exposure of 2-4 pounds $(1-2 \mathrm{~kg})$ of pine needles, whereas others require several sustained days of pine needle consumption.

The pine-needle-induced abortion is similar to a normal parturition; however, most animals have a retained placenta, and many have mucoid or hemorrhagic vaginal discharge (Fig. 2), depression, minimal mammary development, incomplete vaginal dilation, weak uterine contractions or uterine inertia, and dystocia (abnormal or difficult birthing). The retained placenta may persist for $2-3$ weeks. As a result, the common side effects of abortion include uterine infections, lack of milk, and occasionally death.

If abortion occurs in late gestation, the calves may live, but they are generally weak, may not suckle, and require extensive care and nursing. Aborted calves do not have lesions, and fetal development (size, hair, and teeth) is normal for the gestation age. Some cows may not abort,

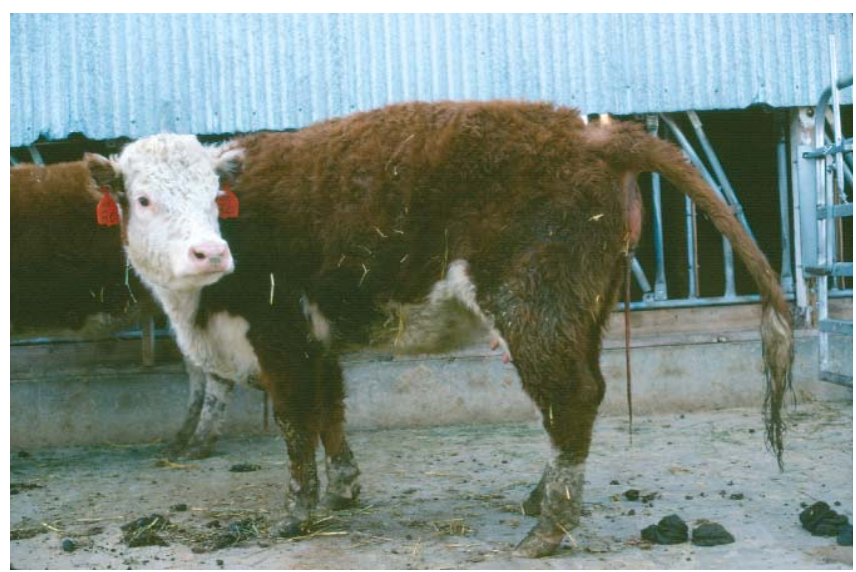

Figure 2. A common symptom of pine-needle-induced abortion is retained placenta and a mucoid or hemorrhagic vaginal discharge. but they develop sporadic vaginal discharges, anorexia, and rumen dysfunction. If they recover, these animals may also deliver small calves that fail to thrive.

\section{Treatment and Management Recommendations}

Presently there is no antidote or treatment to reverse or avoid the abortifacient effects of pine needles. As a result, the current recommendations are that livestock producers avoid exposing pregnant cattle, especially during late gestation, to pine needles, pine bark, and pine tips. Providing adequate food and shelter can help reduce losses. Recent research suggests that pregnant cows be maintained in at least moderate to good body condition when grazing on pine-needle-infested rangelands to reduce consumption of pine needles and risk of abortions. ${ }^{6}$ Moving to a late spring or fall calving period may also be helpful to avoid cows being in the third trimester of pregnancy during cold, snowy winter months.

If an abortion problem does occur, the recommended therapy is to treat the secondary changes or side effects of abortion. Veterinary care and supervision will often be needed to initiate antibiotic, hormone, and steroid therapy for treatment of retained placenta and uterine infections. Also, many of the calves that are born alive may require colostrum and milk supplementation, oxygen therapy, fluid and electrolyte replacement, and antibiotic therapy to survive.

\section{Other Abortifacient Plants}

Although pine needles may be responsible for most of the plant-induced abortions observed in livestock, there are a number of other plants known, or suspected, to cause abortions in livestock. A list of many of these plants is given in Table 2.

\section{Locoweeds}

Locoweeds (species of Oxytropis and Astragalus containing the toxin swainsonine) cause adverse effects on reproductive function in livestock. Locoweed poisoning occurs in all classes of grazing livestock. ${ }^{10}$ Studies using radio-ultrasound to monitor the effects of locoweed on fetal and placental development in ewes made observations similar to the results of others at necropsy: fluid accumulation in the placenta, altered cotyledonary development, and fetal death followed by abortion. Additionally, locoweed may cause vasoconstriction or increased vascular resistance in the fetus similar to that which it causes in cattle at high elevation. The workload on the fetal heart may increase, causing hypertrophy, dilatation, cardiac insufficiency, fluid accumulation, fetal death, and abortion.

Ultrasound studies suggested that fetuses in ewes fed locoweed often die 2-3 days before abortion occurs. It has also been reported that concentrations of specific prostaglandins (a class of lipid-based hormones) are higher in ewes bearing dead fetuses than in those bearing live fetuses. 


\begin{tabular}{|c|c|c|c|}
\hline Plant & Toxicant & Effect & Species \\
\hline False hellebore (Veratrum californicum) & Cyclopamine & Embryonic death & Sheep \\
\hline $\begin{array}{l}\text { Snakeweeds (Gutierrezia sarothrae or } \\
\text { microcephala) }\end{array}$ & Unknown & $\begin{array}{l}\text { Abortion when grown on sandy } \\
\text { soil? }\end{array}$ & Cattle, sheep, goats \\
\hline $\begin{array}{l}\text { Locoweeds (Oxytropis and Astragalus } \\
\text { spp.) }\end{array}$ & Swainsonine & Abortion, embryonic death & All livestock \\
\hline Hairy vetch (Vicia villosa) & Unknown & Abortion & Cattle \\
\hline White popinac (Leucaena leucocephala) & Mimosine & Infertility, abortion & Cattle and pigs \\
\hline Tall fescue (Festuca arundianea) & Ergot alkaloids & Abortion, still births & Horses \\
\hline Nitrate-containing plants & Nitrite & Abortion, fetal death & Ruminants \\
\hline
\end{tabular}

Thus, in the case of locoweed-induced abortion, tissue necrosis after fetal death may stimulate prostaglandin production and subsequent abortion.

Management to avoid locoweed-related toxic, teratogenic (causing birth defects), and abortifacient potential is difficult because of the ubiquitous nature of the plant and its ability to thrive during adverse climatic conditions. Additionally, the generalized and consistent toxicity of locoweeds regardless of plant-growth stage, animal species ingesting it, and its relative palatability, particularly when other forage is scarce (early spring, fall, and winter), make management of locoweeds difficult. Details regarding current management strategies to graze locoweed-infested rangelands are found in the article by Cook et al. in this issue.

\section{Broom Snakeweed}

For years there have been anecdotal reports that the consumption of broom snakeweed (Guterrezia sarothrae) by pregnant cattle will result in abortion. Early research suggested that consumption of broom snakeweed may cause pregnant animals to abort. However, these reports still have not been thoroughly substantiated by rigorous experiments. Interestingly, however, broom snakeweed does contain diterpene acids similar in structure to ICA, the abortifacient compound in pine needles. ${ }^{9}$ Similar to pine-needle-induced abortions, cows that have aborted after consuming broom snakeweed may have retained placentas, which can lead to uterine infection and death. Further information regarding broom snakeweed toxicity is found in the article by Davis et al. in this issue.

\section{Veratrum}

Veratrum californicum (false hellebore) is a common mountain range plant that grows in moist areas and is responsible for the induction of several congenital birth defects in sheep.
The teratogenic compound is a steroidal alkaloid, cyclopamine. ${ }^{11}$ The most widely known malformations include congenital cyclopia and related craniofacial deformities commonly referred to as "monkey faced lamb disease." The facial defects result from neural tube defects induced when pregnant ewes ingest the plant on day 14 of gestation. ${ }^{12} \mathrm{~A}$ high incidence of embryonic death is induced during the first month of gestation. Sheep are the primary species affected by this plant; however, the cyclopic defect has also been experimentally induced in calves and goats. Tracheal stenosis (collapsed trachea) has also been induced in newborn lambs by feeding Veratrum to pregnant ewes on days 31,32 , and 33 of gestation. Tracheal defects resulted in neonatal death from tracheal collapse and suffocation. This type of defect would normally pass unrecognized among other causes of neonatal death.

From a grazing management perspective, two aspects are major factors in reducing losses from an epidemic proportion to insignificant levels in sheep: 1) the greatest losses resulted from a lethal cyclopic facial defect, but the susceptible gestational period is very narrow (approximately day 14); and 2) the Veratrum habitat is limited to very wet riparian areas in high elevation rangeland. Therefore, preventing ewes from grazing in areas where this plant grows until after the rams have been removed for 35 days will significantly reduce the chance of losses.

\section{Conclusions}

Poisonous plants in pastures and ranges have a marked impact on fetal and neonatal survival and development. Some of those plants and their toxins have been discussed in this review. However, there are many more plants on the range, known and unknown, that may also affect the fetus in utero, causing adverse effects on the embryo or fetus. The knowledge of how these plants affect the unborn and 
their consequences on the neonate and ultimately the adult will help us better manage livestock to avoid losses on ranges with these plants. We speculate that with continued advancement in technology we may eventually be able to manipulate embryos, fetuses, dams, or gastrointestinal microorganisms to change the susceptibility of animals to poisonous plants.

Livestock management on western ranges is changing. Enhancing the ability of livestock to graze western ranges containing poisonous plants often leads to a more economical and productive use of these areas. What seems most important here is that, despite the presence of toxic plants, these lands serve as a source of high-quality animal protein for a growing human population. However, further research is needed to identify methods by which poisonous plant-induced harmful effects on grazing animals and the associated economic losses can be reduced.

\section{References}

1. Panter, K. E., and B. L. Stegelmeier. 2000. Reproductive toxicoses of food animals. Veterinary Clinics of North America: Food Animal Practice 16:531-544.

2. Nielsen, D. B., And L. F. James. 1992. Ecconomic impact of poisonous plants on livestock production. In: L. F. James, R. F. Keeler, E. M. Bailey, P. R. Cheeke, and M. P. Hegarty [EDs.]. Poisonous plants: Proceedings of the Third International Symposium. Ames, IA, USA: Iowa State University Press. p. 3-10.

3. Lacey, J. R., L. F. James, and R. E. Short. 1988. Ponderosa pine: economic impact. In: L. F. James, M. H. Ralphs, and D. B. Nielsen [EDs.]. The ecology and economic impact of poisonous plants on livestock production. Boulder, CO, USA: Westview Press. p. 95-106.

4. Gardner, D. R., K. E. Panter, R. J. Molyneux, L. F. James, And B. L. Stegelmeier. 1996. Abortifacient activity in beef cattle of acetyl- and succinylisocupressic acid from ponderosa pine. Journal of Agricultural and Food Chemistry 44:3257-3261.
5. Pfister, J. A., K. E. Panter, and D. R. Gardner. 1998. Pine needle consumption by cattle during winter in South Dakota. Journal of Range Management 51:551-556.

6. Pfister, J. A., K. E. Panter, D. R. Gardner, D. Cook, and K. D. Welch. 2008. Effect of body condition on consumption of pine needles (Pinus ponderosa) by beef cows. Journal of Animal Science 86:3608-3616.

7. Pfister, J. A., And D. C. Adams. 1993. Factors influencing pine needle consumption by grazing cattle during winter. Journal of Range Management 46:394-398.

8. James, L. F., J. W. Call, and A. H. Stevenson. 1977. Experimentally induced pine needle abortion in range cattle. The Cornell Veterinarian 67:294-299.

9. Gardner, D. R., L. F. James, K. E. Panter, J. A. Pfister, M. H. Ralphs, and B. L. Stegelmeier. 1999. Ponderosa pine and broom snakeweed: poisonous plants that affect livestock. Journal of Natural Toxins 8:27-34.

10. James, L. F., W. J. Hartley, and K. R. Van Kampen. 1981. Syndromes of astragalus poisoning in livestock. Journal of the American Veterinary Medical Association 178:146-150.

11. Keeler, R. F. 1969. Teratogenic compounds of Veratrum californicum (Durand). 6. Structure of cyclopamine. Phytochemistry 8:223-225.

12. Binns, W., J. L. Shupe, R. F. Keeler, and L. F. James. 1965. Chronologic evaluation of teratogenicity in sheep fed Veratrum californicum. Journal of the American Veterinary Medical Association 147:839-842.

Authors are Toxicologist, kevin.welch@ars.usda.gov (Welch), Research Biochemist (Davis), Reproductive Toxicologist and Research Leader (Panter), Rangeland Scientist (Pfister), and Research Pharmacologist (Green), Poisonous Plant Research Laboratory, Agricultural Research Service, United States Dept of Agriculture, 1150 E 1400 N, Logan, UT 84341, USA. Published with the approval of the Director as Journal Paper No. 8043 of the Utah Agricultural Experiment Station. A full citation section can be found at http://www.srmjournals.org. 